\title{
RESPONSE OF A LEBANESE ROCK-FILLED DAM TO SEISMIC EXCITATION
}

\author{
SOBHI ALMAWLA, FADI HAGE CHEHADE \& FOUAD KADDAH \\ Modelling Center, Doctoral School of Science and Technology, Saint-Joseph University, Lebanon
}

\begin{abstract}
Old dams were usually constructed using simplified design criteria. Seismic action was not totally computed and included in the dams' sizing procedure, mainly static forces were applied to the dam body and resistance to a seismic excitation of $0.1 \mathrm{~g}$ peak ground acceleration was verified. This can raise stability concerns because, according to its location, the dam could be subjected to stronger earthquakes. The Qaraoun concrete face rockfill dam (CFRD), the first Lebanese dam, built in 1964, is studied here to evaluate overall stability. The highest excitation predicted for the site is defined by seismic hazard assessment, the applied earthquake is the horizontal component of the Tabas earthquake that occurred in Iran in 1978, with a 7.4 magnitude and $0.8 \mathrm{~g}$ ground acceleration, since the specifications of such an earthquake match the required design solicitation. The simulation was performed using the finite element code Plaxis 2D; a numerical model is presented with all calibration steps and assumptions covering the lack of data regarding the materials' properties. A non-linear behaviour was adopted for the rock fill; static and dynamic calculations were performed in order to obtain the permanent deformations, allowing for a judgement regarding the stability of the dam. A final settlement of one metre at the crest and a horizontal displacement of one metre are not threatening values, taking into consideration the level of the reservoir free board, which is $5 \mathrm{~m}$ below the dam crest. Keywords: dam, earthquake, simulation, Plaxis, rock dam, stability, deformation, settlement.
\end{abstract}

\section{INTRODUCTION}

The mission of computing the response of a dam to dynamic and cyclic vibration was and still is considered difficult. The non-linear behaviour of a dams' material and foundation, in addition to poor knowledge about the soil's mechanical properties, could be major constraints, especially for a dam with an execution date in the far past [1]; however, over recent years the geotechnical field has seen remarkable development regarding modelling tasks, allowing a geotechnical engineer to be able to assess the influence of loads and natural actions on the soils, even when the excitation is dynamic.

In 2010, a non-linear stress-strain relationship was applied to the Pushihe dam for a seismic response evaluation. The hyperbolic Duncan EB model was used, based on the element birth and death approach, including a sequential impoundment operation developed by $\mathrm{Yu}$ et al. [2]. The permanent deformations were: $16 \mathrm{~cm}$ horizontal displacement and 37 cm settlement. In 2011, Kerkouri [3] worked on the "Koudiet el m'douar" dam, another earthfilled dam, using the finite element code Plaxis and an elasto-plastic behaviour for the soil. The dam construction phases were considered, including the reservoir filling and the consolidation process before the dynamic load application: the total dam displacement obtained was $7.6 \mathrm{~cm}$ after being shaken by the Parkfield earthquake with a PGA $=3.73 \mathrm{~m} / \mathrm{s}^{2}$. Another concrete face rockfill dam (CFRD) dam case was presented in 2011 by Noorzad [4], the $99 \mathrm{~m}$ Gelevard dam was subjected to the Firoozabad earthquake, with a PGA $=0.14 \mathrm{~g}$. The simulation was performed on Abaqus by the Mohr-Coulomb elasto-plastic behaviour; with a final settlement of the crest at $22 \mathrm{~cm}$. The overall stability was verified, but the author recommended a special adjustment for the concrete-faced slab.

In 2012, Behrouz and Azlan [5] focused on the influence of the material properties on the dam foundation, regarding seismic response. Several models were generated by the ANSYS 
software and they highlighted the impact of any variation on the foundation material. In 2013, Plaisant [6] dealt with the bituminous concrete core rock-filled dam; the Sanokai dam was modelled using Mohr-Coulomb and the hardening soil model available in Plaxis code. A comparison of the simulation results and real observation at the dam site has shown that there is a notable agreement, in terms of signal amplification, between the top and bottom of the dam.

The Taksebt dam, a $76 \mathrm{~m}$ high, clay-core earth-filled dam, was studied in 2015 by Naas and Gueddouda [7] using the Mohr-Coulomb criterion, through the Plaxis FEM code. A seismic excitation of PGA $=0.25 \mathrm{~g}$ was extracted from the record of the Boumerdes earthquake, and the permanently estimated displacements found were: $41 \mathrm{~cm}$ horizontally, and $6.5 \mathrm{~cm}$ vertically. It was remarked upon also that the numerical simulation results were compatible with the empirical method of Swaisgood with regards to the relative crest settlement.

In addition to permanent deformations after seismic actions, the safety factor of the dam's slopes was monitored before and after seismic excitation. In 2015, Selcuk [8] studied the Ambar dam in Turkey for a strong earthquake by the Quake/w FEM tool: the deformations were moderate and the safety factor decreased from 1.35 and 1.87 , to 1.1 and 1.31 , for the upstream and downstream slopes respectively. The material properties were assigned through assumptions of the shear modulus reduction during the cyclic loading, and the seismic record of the Bingol incident 2003 was taken into consideration with PGA $=0.55 \mathrm{~g}$.

In 2017, Auchar Zardari [9] investigated a dam response in Sweden by the FEM method for two earthquakes (the Skellefte'a earthquake and the Virginia earthquake). The Aitik tailings dam was modelled using two different behaviours: the Mohr-Coulomb and the UBCSAND model. The evaluation of excess pore pressure after the dam shook showed a clear increase: the liquefied zone was assigned according to the threshold of excess pore pressure. The induced settlement was not dangerous regarding the free board, and the slope stability was checked with a safety factor of 1.22 in the worst case, which was accepted as per the Ancold guidelines.

\section{QARAOUN DAM DESCRIPTION AND THE SEISMIC FEATURES OF THE SITE}

The Qaraoun Dam is located on the Litani River, in the Central Bekaa valley at an elevation of $800 \mathrm{~m}$ above sea level. Qaraoun Lake, the largest man-made lake in Lebanon, is located at the end point of the middle basin area, and it accumulates 220 million $\mathrm{m}^{3}$. The watershed of Litani River is the largest basin in Lebanon, with an area of about $2170 \mathrm{~km}^{2}$ [10]. Table 1 describes the main features of the Qaraoun dam, and Fig. 1 shows the plan view at the site. The critical section is defined according to the maximum crest height along the dam's length, and its geometry is divided into four parts (Fig. 2): the dam foundation, the concrete slab at the upstream zone ( $40 \mathrm{~cm}$ in width), the stratified rock fill (a minor part of the body of the dam adjacent to the concrete panel) and the dumped rock fill, a major part of the dam.

\subsection{Geology of the site}

The Bekaa and the interior valley of Lebanon are predominantly a limestone terrain with minor proportions of shale and sandstone. The bedrock exposures with marked evidence of weathering are extensive, the soil cover is thin and ranges between $0.5 \mathrm{~m}$ and $2.5 \mathrm{~m}$, the bedrock in this zone consists of white to grey, relatively fine grained, thin bedded, hard to moderately soft strata of limestone, marly limestone, and dolomite. As it was agreed that the site material is the main source for dam body construction, the geological description has helped the quantification of soil parameters in the dam body [11]. 
Table 1: Principal features of the Qaraoun dam. (Source: Litani River Authority.)

\begin{tabular}{|l|c|}
\hline Crest level & 861 above sea level \\
\hline Maximum dam height & $61 \mathrm{~m}$ \\
\hline Crest length & $1090 \mathrm{~m}$ \\
\hline Normal water level & 856 above sea level \\
\hline Reservoir storage capacity & $220 \mathrm{M} \mathrm{m}^{3}$ \\
\hline Total embankment volume & 2 million $\mathrm{m}^{3}$ \\
\hline Total concrete-faced area & $47,000 \mathrm{~m}^{2}$ \\
\hline Thickness of the concrete facing & $40 \mathrm{~cm}^{2}$ average \\
\hline
\end{tabular}

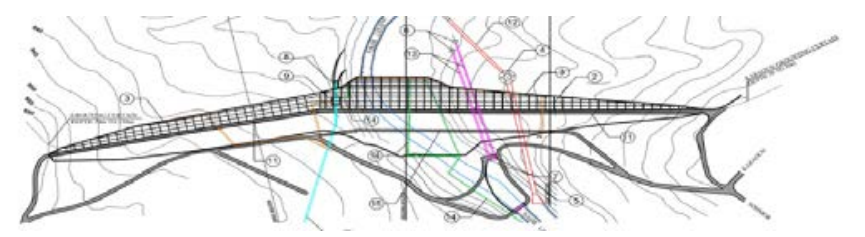

Figure 1: Longitudinal plan view of the dam. (Source: Litani River Authority.)

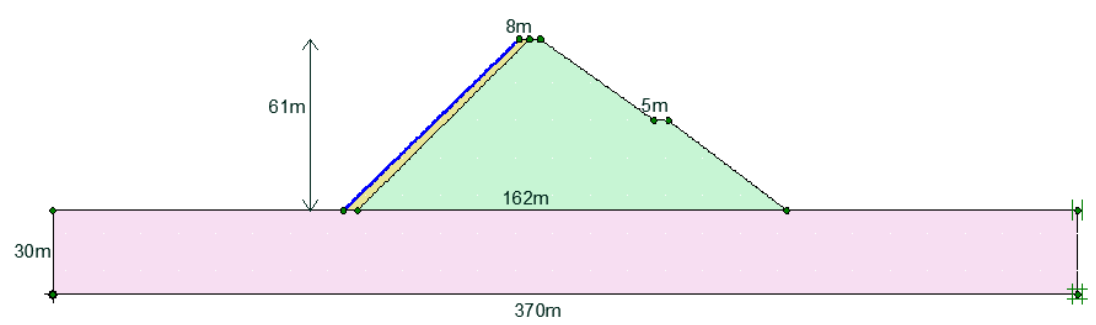

Figure 2: Geometry of the critical section at the maximum height of the dam.

\subsection{Seismic hazard assessment}

Elnashai and Elkhoury [12] stated that seismicity in the eastern Mediterranean could be related to interactions between the continental plates. The Dead Sea region generates about $8-10 \mathrm{~mm} /$ year of slip between Arabia and Africa, and it has caused several earthquakes in history that were of a magnitude $>7$. The simple fault system in the southern region between the Gulf of Aqaba and the pulling apart basin of the Galilee Sea and the Hula depression becomes a system described by compressional structures and numerous braided strike-slip zones in Lebanon. Because the faults continue through Lebanon and Syria, it follows a prominent restraining bend, by which the simple fault trace branches off into several splayed faults, including the well-known Yammouneh fault in Bekaa Valley, the principal extension 
of the Dead Sea fault system, with the Ghab fault in NW Syria (Fig. 3). Qaraoun dam is situated $2.5 \mathrm{~km}$ to the east of the Yammouneh fault that seems to have been the origin of many past earthquakes in the years 1157 (Ms > 7.0 at Hama), 1202 (Ms = 7.5 at Baalbeck), $1759(\mathrm{Ms}=6.6$ at South Bekaa) and $1759(\mathrm{Ms}=7.4$ at Bekaa) [13].

2.2.1 Highest magnitude generated by the Yammouneh fault

One key method used to estimate magnitude is the use of the relationship between the length of the fault trace at the ground surface and the size of earthquake that can be produced by that fault. During the last 40 years, several empirical studies were performed to estimate these relationships and they stated that the earthquake size is linearly proportional to the logarithm of the fault length. One of the widespread relationships is shown in a graph produced by Housner and Jennings in 1982 [14]: Fig. 4 indicates that an earthquake with a magnitude between 7.5 and 8.0 can be produced by the $160 \mathrm{~km}$ rupture length of the Yammouneh fault.

2.2.2 Maximum Design Earthquake and Operating Basis Earthquake

The Maximum Design Earthquake (MDE) and the Operating Basis Earthquake (OBE) can be determined by probabilistic methods [15]. Their average return period $\mathrm{T}_{\mathrm{m}}$ can be calculated from the following equation:

$$
\mathrm{T}_{\mathrm{m}}=\left[1-(1-\mathrm{P})^{1 / \mathrm{Td}}\right]^{-1}
$$

where $\mathrm{P}$ is the probability of occurrence, assumed as $10 \%$ for MDE and $50 \%$ for OBE, and $\mathrm{T}_{\mathrm{d}}$ is the life duration of the dam (100 years). The MDE average return period was calculated as 950 years and the OBE average return period was 145 years. The relationships proposed for the Dead Sea fault system [12] are adopted for the estimation of the MDE and OBE earthquakes, as per the Gutenberg-Richter equations:

$$
\begin{gathered}
\mathrm{Ms}<7.2: \operatorname{LOG}(N \geq \mathrm{Ms})=3-0.73 \mathrm{Ms}, \\
\mathrm{Ms} \geq 7.2: \mathrm{LOG}(N \geq \mathrm{Ms})=14.8-2.73 \mathrm{Ms},
\end{gathered}
$$

where $N$ is the number of earthquakes with magnitude $\geq$ Ms per year.

Thus, $\mathrm{MDE}=7.50$ and $\mathrm{OBE}=7.07$.

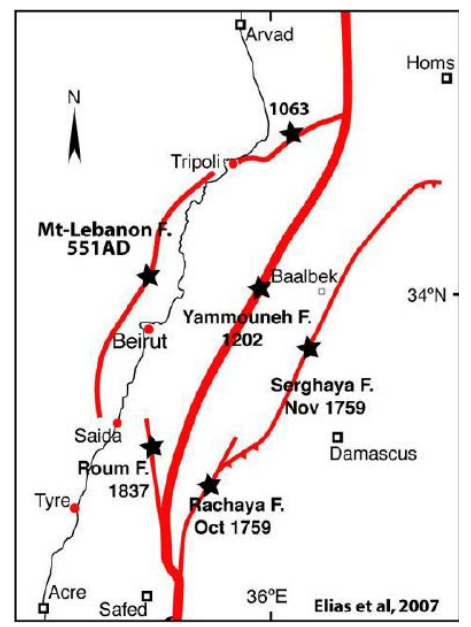

Figure 3: Active faults of the Lebanese restraining bend. (Source: Elias et al., 2007.) 


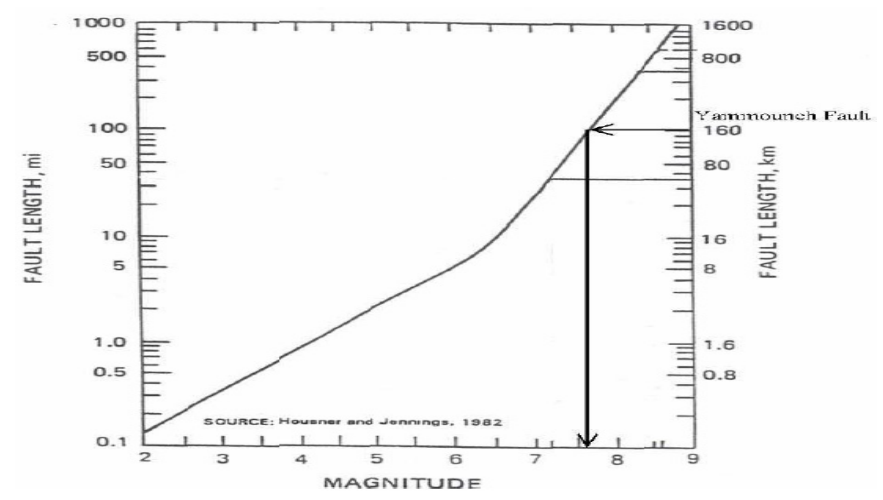

Figure 4: Magnitude of an earthquake produced by a fault, by function of the fault's length [14].

\subsubsection{Estimation of peak ground acceleration}

The peak ground acceleration is evaluated according to the earthquake magnitude and the distance from the seismic source location, which is approximately equal to $2.5 \mathrm{~km}$ from the Yammouneh Fault. Due to unavailability of data to describe the attenuation of ground motion in this part of the world, it is therefore necessary to follow an attenuation relationship from a spectrum of such relationships that had developed worldwide. The approach proposed by Seed and Idriss [16] listed in the curve of Fig. 5 was adopted. The results are:

For $\mathrm{MDE}=7.50$ : $\mathrm{PGA}$ is equal to $0.68 \mathrm{~g}$. For $\mathrm{OBE}=7.07: \mathrm{PGA}$ is equal to $0.66 \mathrm{~g}$.

\section{NUMERICAL ANALYSIS}

The dynamic module of the Plaxis 2D code is used for simulation with a triangular finite element of 6 nodes and plan strain option. The model's dimensions are taken enlarged at the foundation, with absorbent boundaries to avoid any reflection of the seismic waves. As seen in Fig. 6, the mesh element size is selected according to the convergence conditions defined

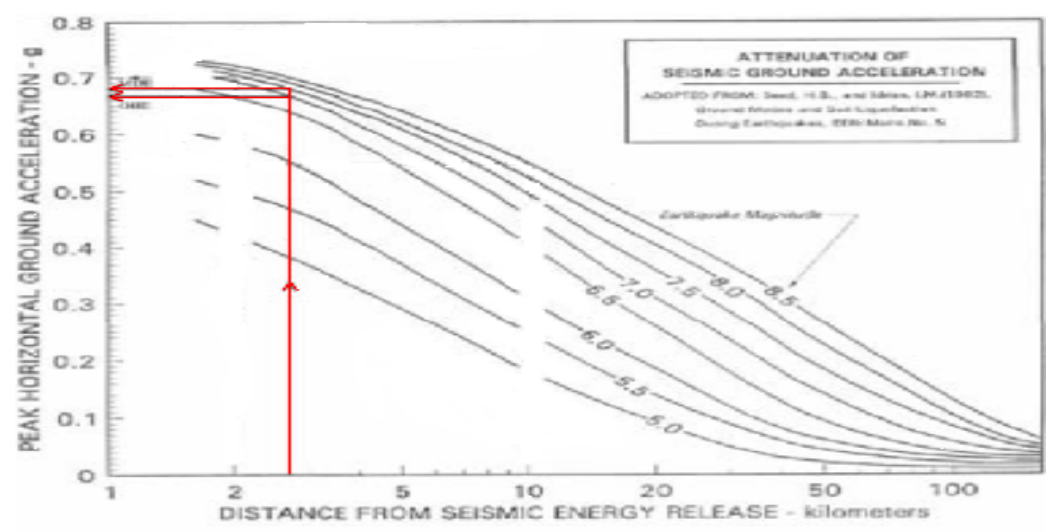

Figure 5: Estimation of peak ground acceleration [16]. 
by a mesh parametric study [17]. The water reservoir was not considered in the dynamic calculations: the dam was modelled only in a dry situation.

\subsection{Seismic excitation signal}

The seismic hazard study leads to the design of earthquakes with $0.68 \mathrm{~g}$ in ground acceleration and 7.5 in magnitude (as highest values). Because no registrations for the past severe earthquakes in Lebanon are available, we used the Tabas earthquake that occurred in Iran in 1978: 33 seconds of excitation with $\mathrm{PGA}=0.8 \mathrm{~g}$ and $\mathrm{M}=7.4$. The signal input shown in Fig. 7 is applied at the bottom of the model.

\subsection{Dam material properties and model calibration}

The rigid foundation and the concrete face of the dam were considered to remain in the elastic zone during the shaking period. The properties of these zones are described in Table 2, with the concrete face being modelled as a beam, with the elasticity and inertia features presented as well. The behaviour of the dumped and stratified rock fill is simulated by a hardening plastic soil model integrated in Plaxis; it is a convenient model, due to the possibility of expansion for the yield surface in the presence of plastic straining, and because this model reflects the non-linearity of soil behaviour [17].

The friction angle of the rock fill changes with the normal effective stress applied on the material. After referring to the empirical studies found in Leps in 1970 [19] and the findings of the static state stresses in the Qaraoun dam (Fig. 8), we used the added lines in the Leps' chart to estimate this parameter (Fig. 9). The average internal friction angles are 45 and 52 for the dumped and the stratified rock fill, respectively, according to the normal stress values in each zone.

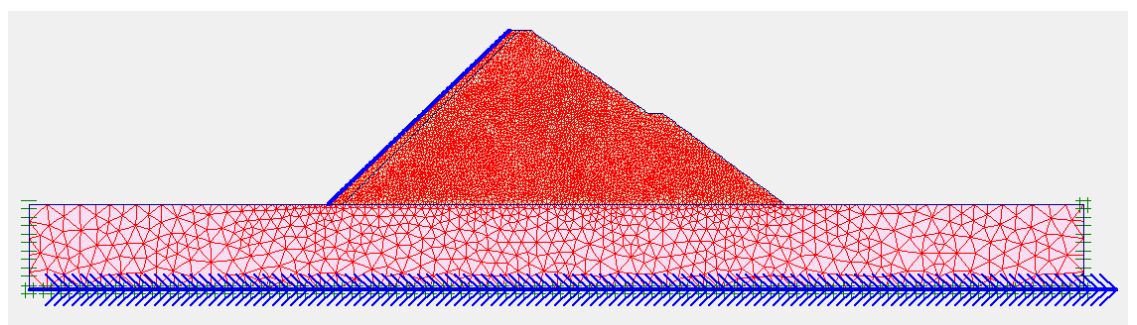

Figure 6: Mesh in a finite element model.

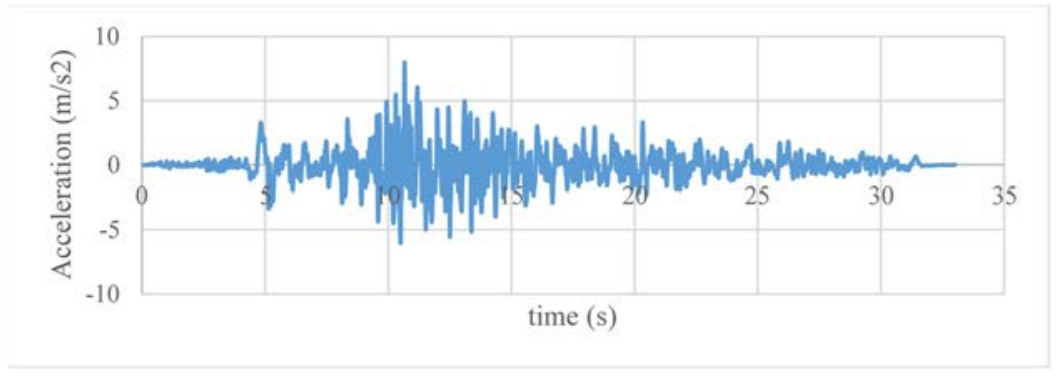

Figure 7: Accelerogram from the Tabas earthquake (E/W). 
Table 2: Elastic parameters of the dam's foundation and the concrete face.

\begin{tabular}{|l|c|c|c|c|c|c|}
\hline & $\begin{array}{c}\text { Unit weight } \\
\left(\mathrm{kN} / \mathrm{m}^{3}\right)\end{array}$ & $\begin{array}{c}\text { Young } \\
\text { modulus } \\
(\mathrm{Mpa})\end{array}$ & $\begin{array}{c}\text { Poisson's } \\
\text { ratio }\end{array}$ & $\begin{array}{c}\text { Normal } \\
\text { rigidity } \\
(\mathrm{kN} / \mathrm{m})\end{array}$ & $\begin{array}{c}\text { Flexural } \\
\text { rigidity } \\
\left(\mathrm{kN} . \mathrm{m}^{2} / \mathrm{m}\right)\end{array}$ & $\begin{array}{c}\text { Equivalent } \\
\text { thickness } \\
(\mathrm{m})\end{array}$ \\
\hline Foundation & 22.43 & $4.67 \times 10^{3}$ & 0.25 & - & - & - \\
\hline Concrete face & 24 & $2.4 \times 10^{4}$ & 0.21 & $1.056 \times 10^{7}$ & $1.4 \times 10^{5}$ & 0.4 \\
\hline
\end{tabular}

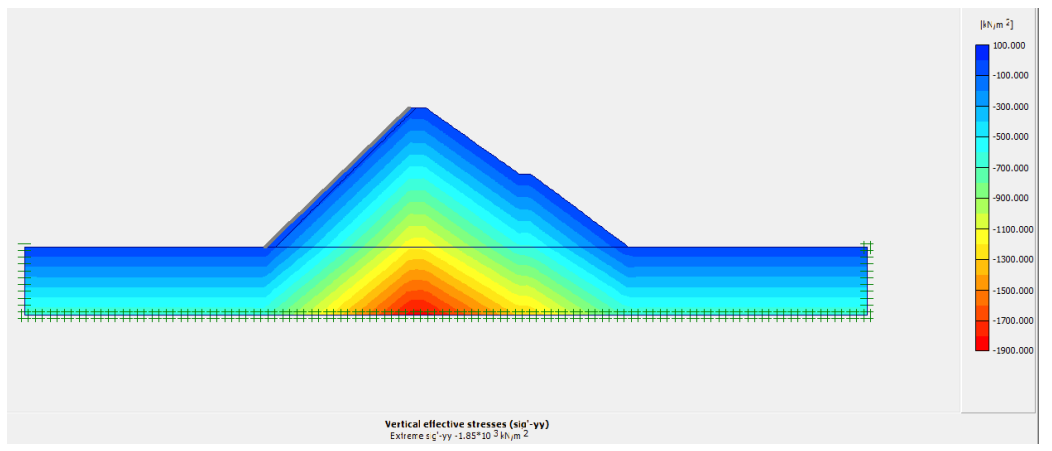

Figure 8: Static vertical stress distribution in the dam.

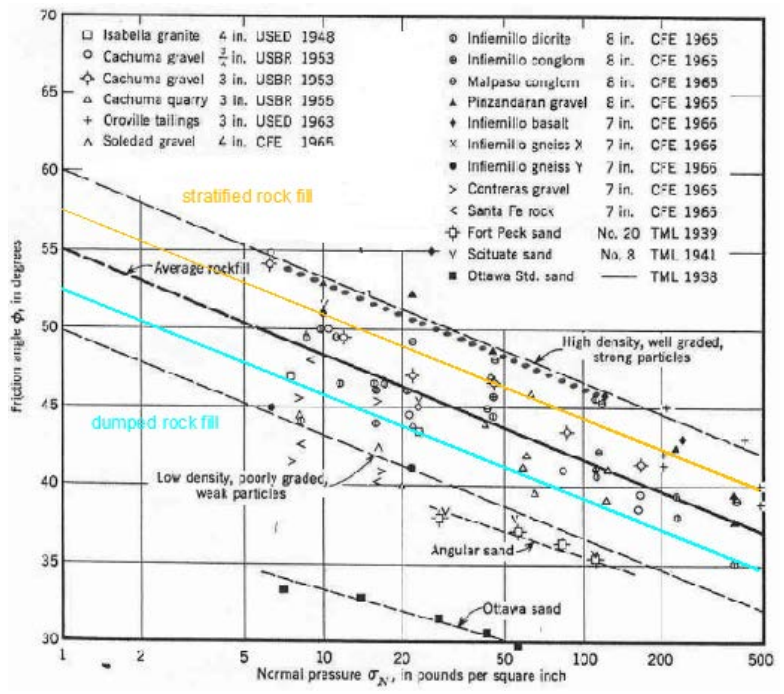

Figure 9: Variation of friction angle, according to normal pressure [19].

The shear modulus $\mathrm{G}$ and damping coefficient $\mathrm{D}$ are directly affected by the level of shear strain in the material. In 1993, EPRI [20] obtained the specific curves describing the variation 
of these moduli, according to their shear strain percentage. In modelling the Qaraoun dam, these curves were chosen (Fig. 10).

The maximum shear modulus $\mathrm{G}$ is obtained by the Seed-Idriss equation:

$$
\mathrm{G}_{\max }=1000 \times \mathrm{K}_{2 \max } \times \sigma_{\mathrm{m}}{ }^{0.5},
$$

where $\mathrm{K}_{2 \max }$ is an empirical factor depending on the material used and its relative density (values were extracted from publications with values of 80 for dumped and 120 for stratified rock fill) [21]; and $\sigma_{\mathrm{m}}$ the effective mean stress, evaluated from the static state of the dam performed in the first phase of the modelling process.
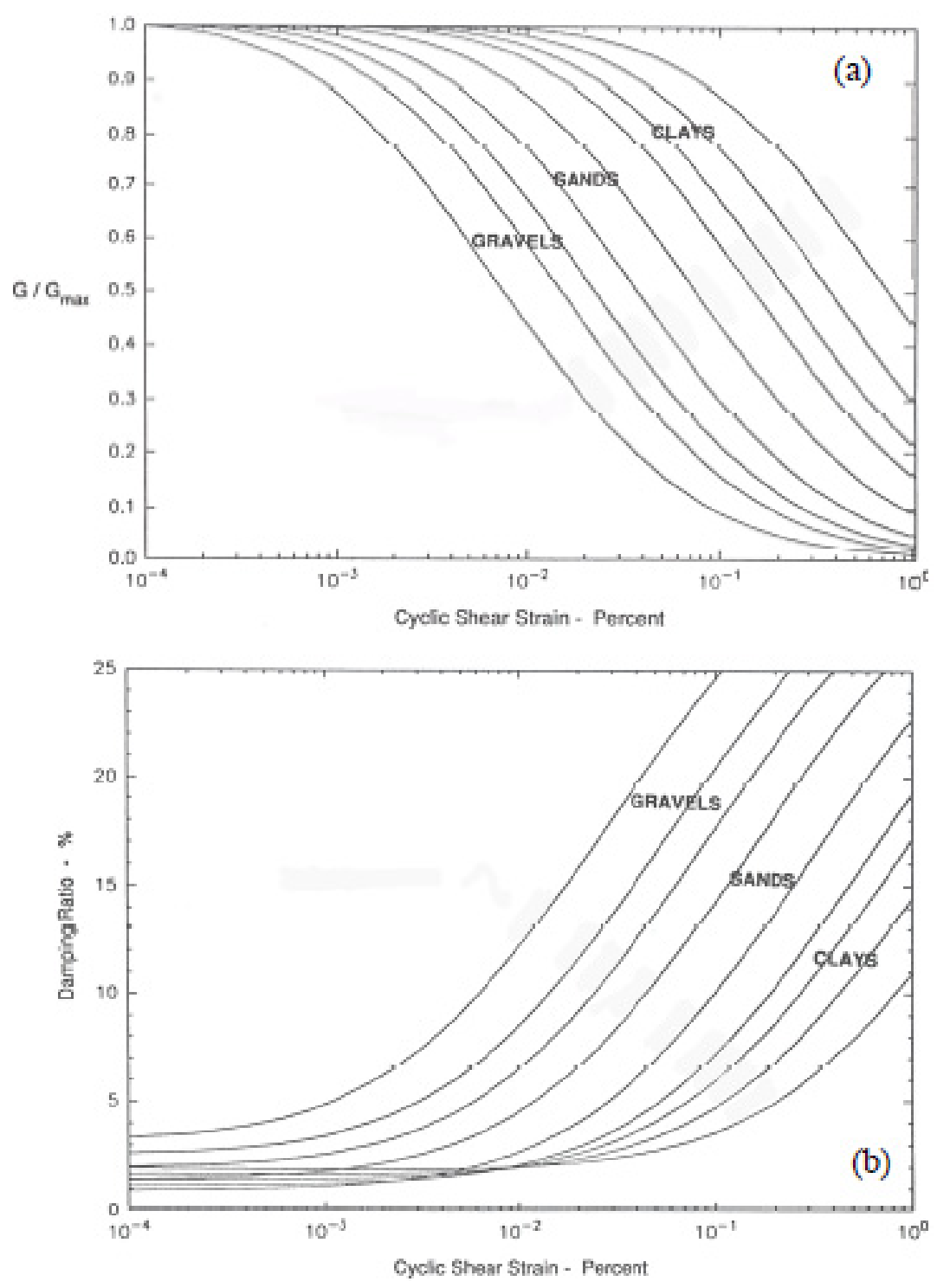

Figure 10: Shear modulus and damping variations, according to shear strain [20]. 
The average mean effective pressure for each zone of the dam is considered for the assumption of the maximum shear modulus:

$$
\sigma_{\mathrm{m}}=\frac{\left(\sigma_{1}+\sigma_{2}+\sigma_{3}\right)}{3} \text {. }
$$

For the dumped rock fill: $\sigma_{\text {m-average }}=218 \mathrm{KPa}=4542 \mathrm{psf}\left(\mathrm{G}_{\text {dumped-max }}=258794 \mathrm{KPa}\right)$. For the stratified rock fill: $\sigma_{\mathrm{m} \text {-average }}=19.6 \mathrm{KPa}=408 \mathrm{psf}\left(\mathrm{G}_{\text {stratified-max }}=116394 \mathrm{KPa}\right)$.

Once determined, the obtained shear modulus allows for the calculation of the shear wave velocity in each component of the dam body [22], according to the relationship:

$$
\mathrm{G}_{\max }=\mathrm{D} \times \mathrm{V}_{\mathrm{s}}^{2} \text {. }
$$

Then the equivalent velocity of the dam-foundation system can be assigned as per the following relationship:

$$
V s_{\text {equ }}=\left(\mathrm{V}_{\text {fond }} \times \mathrm{H}_{\text {fond }}+\mathrm{V}_{\text {dam }} \times \mathrm{H}_{\text {dam }}\right) /\left(\mathrm{H}_{\text {total }}\right) .
$$

Here, $\mathrm{Vs}_{\text {equ }}=548 \mathrm{~m} / \mathrm{s}$ was the value for the whole system. The natural frequencies are a function of this equivalent velocity and the total height, $\mathrm{h}$ :

$$
\mathrm{F}_{\mathrm{n}}=\frac{\mathrm{V}_{\mathrm{seq}}(2 \mathrm{n}+1)}{4 \mathrm{~h}} \text {. }
$$

So, $\mathrm{F}_{0}=1.5 \mathrm{~Hz}$ and $\mathrm{F}_{1}=4.5 \mathrm{~Hz}$ are the first frequencies of the system. Calculation of those frequencies is required in order to define the Rayleigh parameters $\alpha \& \beta$, which calibrate the damping in the finite element model:

$$
\alpha+\omega^{2} \beta=2 \varepsilon \omega \text {. }
$$

For each damping level $\varepsilon$, the values of $\alpha \& \beta$ were calculated taking into consideration the natural angular frequency $\omega$. The hardened soil model requires specific additional parameters: $\mathrm{E}_{50}{ }^{\text {ref }}, \mathrm{E}_{\text {oed }}{ }^{\text {ref }}$ and $\mathrm{E}_{\mathrm{ur}}{ }^{\text {ref }}$ representing the plastic strain due to primary deviatoric loading, the plastic straining due to primary compression and the elastic unloading/ reloading, respectively [23]. To evaluate those parameters, the following set of relationships [23] was implemented consecutively:

$$
\begin{gathered}
\mathrm{E}_{i}=2 \mathrm{G}_{\max }(1+\mathrm{V}), \\
\mathrm{E}_{50}^{\text {ref }}=\mathrm{E}_{\mathrm{i}}(2-\mathrm{Rf}) / 2, \\
\mathrm{E}_{\text {oed }}^{\text {ref }}=\mathrm{E}_{50}{ }^{\text {ref }}(1-\mathrm{V}) /(1+\mathrm{V})(1-2 \mathrm{~V}), \\
\mathrm{E}_{\mathrm{ur}}^{\text {ref }}=3 \times \mathrm{E}_{50}{ }^{\text {ref }},
\end{gathered}
$$

where $V$ is the Poisson's ratio ( 0.33 for rock fill material) and $R_{f}$ the rupture ratio between the ultimate deviatoric stress and the asymptotic value of the shear resistance [23] $\left(R_{f}=0.9\right.$ is a suitable value). In addition, the stiffness variation with the stress level is expressed by the power law $\mathrm{m}$, for similar type of soils $\mathrm{m}=0.4$ [18].

In the first simulation executed with $G=G_{\max }$ and the shear strain level of $10^{-4 \%}$, the results of the shear strains were not compatible to the initial assumption, so another simulation was repeated, but with another shear modulus and damping factor according to the shear strain level in the output of the previous iteration. This process continued until a state of convergence was reached, where the shear strain level of the input, which defines the values of $G$ and $D$ is observed in the output. We needed four simulations before the convergence that occurs for an average shear strain of $3 \times 10^{-3} \%$, the reduction of the shear 
modulus was about $30 \%$ and the damping factor was $5 \%$. The summary of the geotechnical parameters used during the first iteration are shown in Table 3.

\subsection{Results of the simulation}

The maximum horizontal displacement at the end of the earthquake is $1.08 \mathrm{~m}$ (Fig. 11): this highest value is noted at the slopes zone, with left displacement at the upstream slope and right displacement at the downstream slope. The points along the vertical axis of the dam are subjected to a maximum horizontal displacement of $0.5 \mathrm{~m}$, at about two-thirds the height (Fig. 12). The critical vertical deformations encountered are $1.02 \mathrm{~m}$ near the crest (Fig. 13); and, because the free board is $5 \mathrm{~m}$ lower than the crest, settlement is not dangerous and no overtopping should occur. After observing the crest midpoint settlement during the shaking period (Fig. 14), it reached a $97 \mathrm{~cm}$ peak, with the curve shape compatible to the acceleration of the earthquake, since the major settlement started after the first $10 \mathrm{~s}$, when the peak acceleration of the input signal was detected. The vertical displacement of the dam axis points increases linearly from the bottom of the dam up to the crest (Fig. 15). The signal amplification was about 1.6 times, the crest acceleration peak value was $12.9 \mathrm{~m} / \mathrm{s}^{2}$ and the input signal peak was $7.97 \mathrm{~m} / \mathrm{s}^{2}$ (Fig. 16).

Table 3: Parameters of the dam body material in a hardened soil model.

\begin{tabular}{|c|c|c|c|c|c|c|c|}
\hline & $\begin{array}{c}\text { Unit } \\
\text { weight } \\
\left(\mathrm{KN} / \mathrm{m}^{3}\right)\end{array}$ & $\begin{array}{c}\mathrm{E}^{\mathrm{ref}}{ }_{50} \\
(\mathrm{Mpa})\end{array}$ & $\begin{array}{c}\mathrm{E}^{\mathrm{ref}}{ }_{\mathrm{oed}} \\
(\mathrm{Mpa})\end{array}$ & $\begin{array}{c}\mathrm{E}^{\mathrm{ref}}{ }_{\text {ur }} \\
(\mathrm{Mpa})\end{array}$ & $\begin{array}{c}\text { Poisson's } \\
\text { ratio }\end{array}$ & Cohesion & $\begin{array}{c}\text { Friction } \\
\text { angle }\end{array}$ \\
\hline $\begin{array}{c}\text { Dumped } \\
\text { rock fill }\end{array}$ & 19.22 & 378 & 560 & 1135 & 0.33 & 0 & 45 \\
\hline $\begin{array}{c}\text { Stratified } \\
\text { rock fill }\end{array}$ & 20.82 & 170 & 252 & 511 & 0.33 & 0 & 52 \\
\hline
\end{tabular}

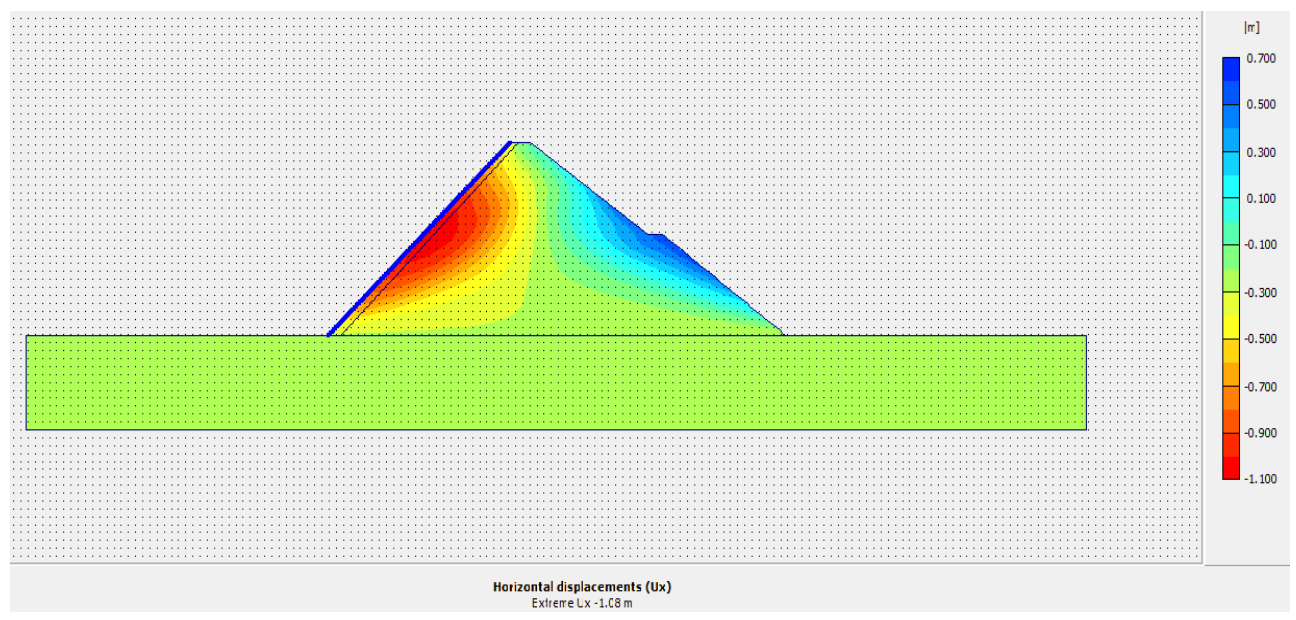

Figure 11: Horizontal permanent displacement. 


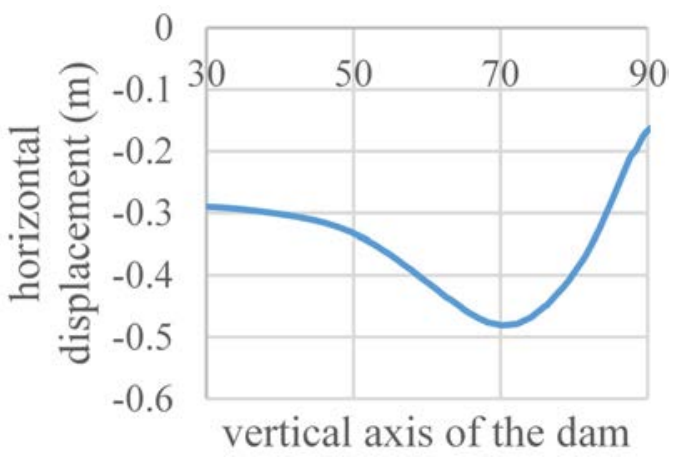

Figure 12: Horizontal deformation of the dam axis at the end of excitation.

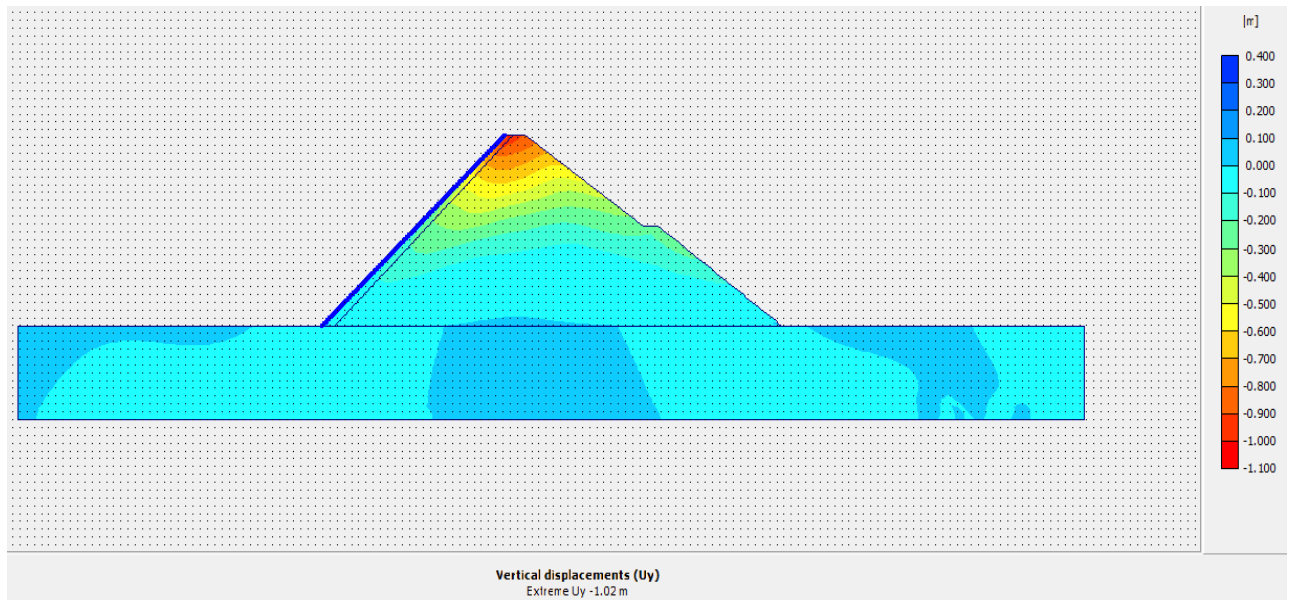

Figure 13: Vertical permanent displacement.

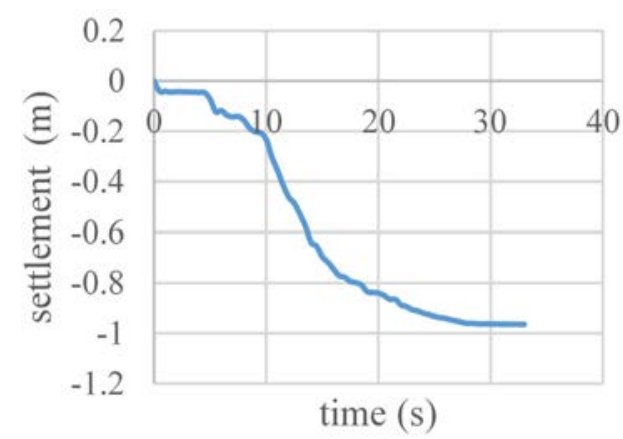

Figure 14: Settlement of dam crest during the excitation period.

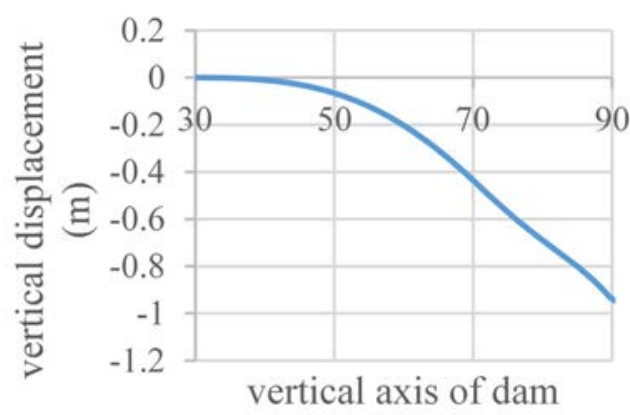

Figure 15: Vertical deformation of the dam axis as the end of excitation. 


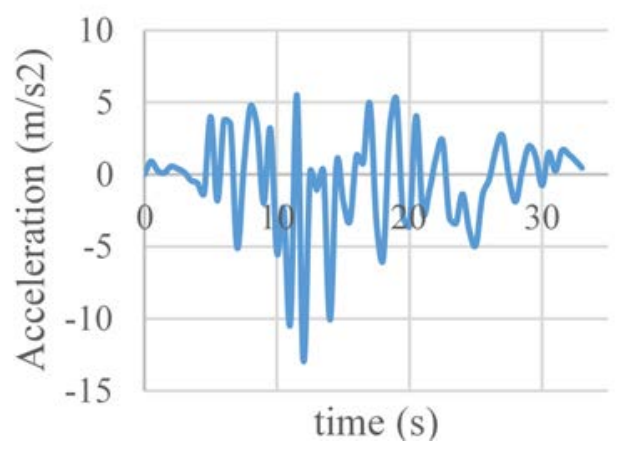

Figure 16: Acceleration of crest points during the excitation period.

\section{CONCLUSIONS}

This study has shown us that the Qaraoun dam will be able to resist a strong earthquake with no significant dam hazard, as the overall stability is verified. Specific attention is to be made for the concrete face, in view of the maximum lateral displacement obtained in the slope zones, to avoid any cracks that could weaken this element, which is responsible for waterproofing the dam. The upper drain lines controlling the free board level should be checked continuously, to preserve the $5 \mathrm{~m}$ difference from the crest. The estimated response is based on an iterative procedure and the summary of similar work quantifying the geotechnical dynamic parameters, due to a lack of data for the dam's rock fill. Our results are in good agreement with other studies on the topic of the seismic response of rock fill. The non-linearity of the soil is taken into account, as well as its plasticity; variations in the stiffness properties were applied according to the state of the existing shear strain in the rock fill.

\section{REFERENCES}

[1] ICOLD, Fourth benchmark workshop on numerical analysis of dam, Paris, France. International Committee on Large Dams and French Committee, 1994.

[2] Yu, H., Li, S., Liu. Y. \& Zhang, J., Non-linear analysis of stress and strain of concretefaced rock fill dam for sequential impoundment process. Mathematical and Computational Applications, 15(5), pp. 796-801, 2010.

[3] Kerkouri, A., Analyse du Comportement Dynamique du Barrage de Koudiet el M'douar sous Sollicitations Sismiques, Université Hadj Lakhdar-Batna, 2011.

[4] Noorzad, A., Dynamic analysis of concrete face rock fill dams (CFRD) using Abaqus software. Proceedings of the Sixth International Conference on Dam Engineering, Lisbon, Portugal, 2011.

[5] Behrouz, G. \& Azlan, B.A., Effect of Material Property in Foundation during Earthquake on the Embankment, International Scholarly Research Network, ISRN Civil Engineering, 2012.

[6] Plaisant, A., Analyse Numérique du Comportement Sismique d'un Barrage en Enrochement avec un Noyau en Béton Bitumineux, Département Des Génies Civil, Géologique et des Mines, École Polytechnique de Montréal, 2013.

[7] Naas, A. \& Gueddouda, M.K., Modélisation et simulation numérique de la stabilité des pentes dans les barrages en terre durant un séisme,cas du barrage de taksebt -tizi 
ouzou. Proceedings of the Thirteenth Arab Structural Engineering Conference, University of Blida, 2015.

[8] Selcuk, M., Seismic response of Ambar dam to recorded earthquake. International Journal of Advanced Research, 3(11), pp. 979-994, 2015.

[9] Auchar Zardari, M., Numerical analyses of earthquake induced liquefaction and deformation behaviour of an upstream tailings dam. Advances in Materials Science and Engineering, Article ID 5389308, 2017. DOI: 10.1155/2017/5389308.

[10] The Litani River Authority. www.litani.gov.lb.

[11] Interim report on Qaraoun dam site, vol $1 \& 2$, Litani river basin development staff Lebanon, June 1953.

[12] Elnashai, A. \& Elkhoury, R., Earthquake Hazard in Lebanon, Imperial College Press: London, 2004.

[13] Ambraseys, N.N. \& Barazangi, M., The 1759 earthquake in the Bekaa valley: implications for earthquake hazard assessment in the eastern Mediterranean region. Journal of Geophysical Research, 94(B4), pp. 4007-4013, 1989.

[14] Housner, G.W. \& Jennings, P.C., Earthquake Design Criteria, EERI Monograph Series, Earthquake Engineering Research Institute: Oakland, CA, 1982.

[15] ICOLD, Bulletin 72, Selecting seismic parameters for large dams, guidelines, 2010.

[16] Seed, H.B. \& Idriss, I.M., Ground Motions and Soil Liquefaction During Earthquakes, Earthquake Engineering Research Institute: Berkeley, CA, p. 134, 1982.

[17] Plaxis, Dynamic Manual, 2007.

[18] Makdessi, F., Seismic Deformations of the Qaraoun Dam, Litani Basin Management Support Program, 2012.

[19] Leps, T.M., Review of shearing strength of rock fill. Journal of the Soil Mechanics and Foundations Division, 96(4), pp. 1159-1170, 1970.

[20] EPRI, Guidelines for Determining Design Basis Ground Motions, Electric Power Research Institute, 1-5, EPRI TR-102293, 1993.

[21] Kulezsa, New Exchequer Dam Report on Stability Analysis, Merced Irrigation District, 1987.

[22] Kramer, Geotechnical Earthquake Engineering, University of Washington, PrenticeHall International Series in Civil Engineering and Engineering Mechanics, 1996.

[23] Plaxis, Material Models Manual, 2007. 